\title{
Sunburn in a Premobile Child due to Neglect: A Case Report
}

\section{Mehmet Cenk Belibağlı*}

Faruk Arıkan Aile Sağlığı Merkezi, Bahçelievler Mah., 9018 Sokak, No:26, 46100, Merkez, Kahramanmaraş, Türkiye

\begin{abstract}
Sunburn is a rare finding in infants which requires an analytical approach by physicians and parents. This case report aims to emphasize the importance of sunburn cases in infants who have more sensitive skin and potential to deteriorate.

This is a case of thirty-one days old boy with a rash, edema with bulla spreading from the left temporal and parietal area to the left part of his neck, covering almost the half of his head with an approximate $8 \%$ first to second degree burn area. Sunburned boy was approached well and healed gradually without any complications.
\end{abstract}

Health care workers should be aware that infant skin is much more sensitive and sunburn can occur easier and deeper and caregivers should be informed at every possible opportunity.

Keywords: Burn; Sunburn; Infant; Parental care; Skin cancer

\section{Introduction}

Skin, the epidermal barrier, carries out functions of photo and chemical protection, thermoregulation, immune care, hormonal synthesis, perception and fluid loss prevention almost at the same level in every phase of life with minor differences [1]. However, when traumatized, those slight differences have major effects on the clinical outcome. Studies suggest that despite the general acceptance of transepidermal water loss (TEWL) in full-term infants is close to that of healthy adults, skin barrier development is still in process until the first year is completed [2]. Additionally, infant skin is reported to have higher rate of water and absorption and loss of water is processed much faster, infants also have thinner stratum corneum and papillary dermis [3]. Infants are more susceptible to ultraviolet (UV) light and sunburn may occur faster since the skin preserves much less melanin [4]. This is a case of a neglected infant who was exposed to sun for a short duration and developed sunburn.

\section{Case Report}

A thirty-one days old boy was presented to our burn center outpatient clinic with a rash, slight edema and bulla formation, spreading from the left temporal and parietal area to the left part of his neck, covering almost the half of his head and left side of his face with an approximate $8 \%$ first-second degree burn area (Figure 1). His

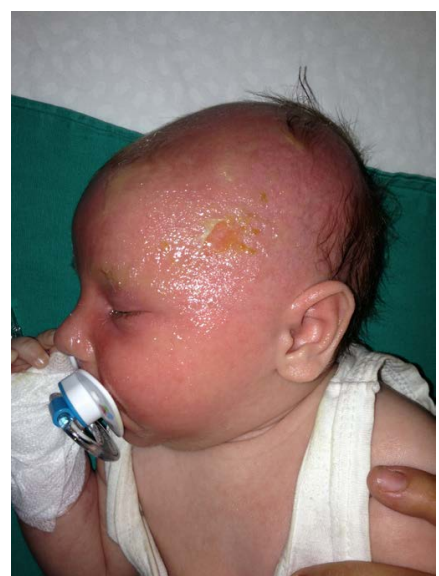

Figure 1: Rash, slight edema and bulla formation, spreading from the left temporal and parietal area to the left part of his neck, covering almost the half of his head due to exposure to sun. mother told that she may have left her boy under the midday sun for an hour a day prior to admission. She told us that she wanted to treat the burn by her methods but by the anxious relatives she was forced to take the baby to a doctor. The boy was presented to our clinic approximately 20 hours after exposure to sun. He was uneasy and crying. His vital signs were: pulse: $98 / \mathrm{min}$., blood pressure: $90 / 60 \mathrm{mmHg}$, temperature: 36.6 and respiratory rate: $28 / \mathrm{min}$. The physical examination revealed no abnormalities except for rash, slight edema and bulla formation covering a quarter of the sunburned area. Personal and family histories were uneventful. The boy was hospitalized. Initially, he was catheterized and dextrose monohydrate $3.33 \%$ and sodium chloride $0.3 \%$ with 10 $\mathrm{meq} / \mathrm{L} \mathrm{KCl}$ solution was given at $4 \mathrm{cc} / \mathrm{kg} /$ hour rate. $2 \mathrm{ml}$ of $20 \mathrm{mg} / \mathrm{ml}$ paracetamol solution was given orally twice a day. The burned area was treated with topical oxytetracycline hydrochloride ointment which was renewed daily.

There were no complications and the symptoms resolved gradually within a week.

\section{Discussion}

Our patient was a thirty-one days old infant and thus should be considered in the high risk age group. The treatment algorithm in burns includes fluid replacement, debridement of dead skin tissue and sterile wound dressings with second degree burns and more severe cases requiring hospitalization. Especially, in infants on breastfeed adequate fluid replacement can only be made via intravenous catheterization. Our patient was hospitalized and adequate hydration and pain management was performed. Topical oxytetracycline hydrochloride ointment was performed and renewed daily. Significant recovery was observed by the third day and the patient was discharged and referred to burn outpatient clinic. By the eighth day burned area was fully epithelialized and follow up was ended.

*Corresponding author: Mehmet Cenk Belibağlı, Faruk Arıkan Aile Sağlığı Merkezi Bahçelievler Mah., 9018 Sokak, No:26, 46100, Merkez, Kahramanmaraş, Türkiye, Tel: +90 53371087 62; E-mail: mcbelibagli@yahoo.com

Received August 23, 2013; Accepted September 06, 2013; Published September 12, 2013

Citation: Belibağı MC (2013) Sunburn in a Premobile Child due to Neglect: A Case Report. General Med 1: 115. doi: 10.4172/2327-5146.1000115

Copyright: ( 2013 Belibağlı MC. This is an open-access article distributed under the terms of the Creative Commons Attribution License, which permits unrestricted use, distribution, and reproduction in any medium, provided the original author and source are credited. 